Check for updates

Cite this: RSC Adv., 2017, 7, 49015

Received 28th August 2017

Accepted 12th October 2017

DOI: $10.1039 / c 7 r a 09470 a$

rsc.li/rsc-advances

\section{Cochinchinenin $C$, a potential nonpolypeptide anti-diabetic drug, targets a glucagon-like peptide-1 receptor}

\begin{abstract}
Yijie Sha, Yunfeng Shi, Bing Niu* and Qin Chen (D)*
The glucagon-like peptide-1 (GLP-1) receptor is currently being explored as a therapeutic target for antidiabetic drugs. GLP-1 analogs possess therapeutic effects similar to those of other anti-diabetic drugs such as guanidine and sulfonylureas but do not cause hypoglycemia and gastrointestinal discomfort. GLP-1 has the ability to reduce blood glucose in a glucose-dependent manner. Several GLP-1 analog agonists have been developed. However, polypeptide drugs are easily degraded by DPP4 in vivo. Therefore, the focus is now on the development of nonpolypeptide anti-diabetic drugs targeting the GLP-1 receptor. In this study, computer-aided drug design was applied to search for potential molecules of this type. Cochinchinenin C, extracted from sangusis draconi, interacted well with GLP-1 receptor via hydrophobic interaction, which was confirmed by fluorescence spectroscopy and molecular simulation. In cell experiments, it was demonstrated that pancreatic beta cells promoted insulin secretion upon treatment with cochinchinenin C, and increases of intracellular CAMP and ATP levels also occurred, indicating GLP-1 receptor activation and glucose metabolism. These results showed that cochinchinenin $\mathrm{C}$ has potential for the development of drugs for treating diabetes.
\end{abstract}

\section{Introduction}

Type 2 diabetes mellitus, the most common type of diabetes mellitus, is one of the most prevalent noncommunicable diseases globally. According to a report from the International Diabetes Federation, there are more than 415 million diabetes patients worldwide. It has also been estimated that there will be more than 642 million of such patients by 2040. Diabetes occurs in adults due to insulin resistance and inadequate insulin secretion, which result in elevated blood glucose levels. ${ }^{1,2}$ Drugs for treating diabetes based on different targets have been developed for the treatment of type 2 diabetes mellitus. Currently, the most widely used therapeutic drugs include guanidine and sulfonylureas, but they also have disadvantages. ${ }^{3,4}$ For example, guanidine causes the adverse effect of gastrointestinal discomfort, while sulfonylureas can cause hypoglycemia owing to a sustained effect of insulin secretion. ${ }^{5}$ Hence, researchers are looking for safer, more curative diabetes drugs with fewer side effects. Glucagon-like peptide-1 receptor (GLP-1R) belongs to the glucagon receptor subfamily in the Gprotein-coupled receptor B family, which is distributed in pancreatic cells, and the gastrointestinal, cardiovascular, pulmonary, and central nervous systems. ${ }^{6,7}$ In early 1979, an incretin called GLP-1 was identified, which is a peptide secreted

Shanghai Key Laboratory of Bio-Energy Crops, School of Life Sciences, Shanghai University, Shanghai, P. R. China.E-mail: chenqincc@staff.shu.edu.cn; Bingniu@ shu.edu.cn by Langerhans cells derived from the end of the jejunum, ileum, and colon. GLP-1 do not promote formation of insulin, but promote excretion of the hormone. ${ }^{8}$ One of the main disadvantages of GLP-1 analogs is that they do cause gastrointestinal discomfort like guanidine, ${ }^{9,10}$ but GLP-1 analogs have the better therapeutic effect. As a glucose-dependent hormone, GLP-1 does not exhibit hypoglycemic effects when the body's blood sugar level is normal. A study found that GLP-1 activated intracellular cAMP in a glucose-dependent manner and then promoted the synthesis of PDX-1 transcription factors, finally promoting the secretion of insulin. ${ }^{11}$ A series of GLP-1 analog agonists have been developed, such as exendin-4, eventide, and liraglutide. ${ }^{12,13}$ However, these GLP-1 receptor agonists are easily degraded by DPP4 in vivo and lose their efficacy. ${ }^{14}$ Therefore, the exploration of nonpeptide GLP-1 receptor agonists has gradually become a focus in the development of GLP-1 receptor agonists. Research on nonpeptide GLP-1 receptor agonists is currently underway. In support of this, Wang et al. established a high-throughput drug screening model for searching for potential nonpeptide GLP-1 receptor agonists.

Sangusis draconis, derived from Daemonorops spp., is mainly composed of flavonoids. Among them, more than $60 \%$ of active compounds belong to dihydrochalcone, including cochinchinenin C (Fig. 1) ${ }^{15}$. Sangusis draconis has numerous pharmacological functions, such as anti-blood-stasis, anticoagulation, and blood-sugar-lowering effects. ${ }^{16,17}$ Increasing research is now focusing on how sangusis draconis can play a role in the 


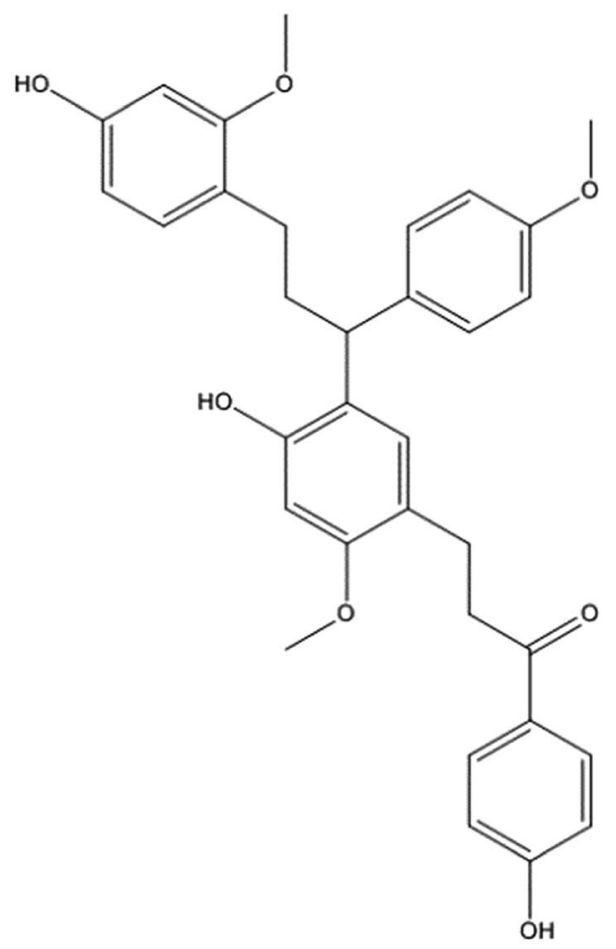

Fig. 1 The molecular structure of cochinchinenin C.

treatment of diabetes. Zhang et al. used a rat hyperglycemia model to reveal that sangusis draconis had a good hypoglycemic effect and could increase insulin secretion. ${ }^{18}$ Research on the mechanism behind sangusis draconis's hypoglycemic effect is currently ongoing.

As the structures of biological macromolecules are continually being determined and computer science continues to develop, computer-aided drug design (CADD) has become widely used in the research and development of leading compounds. ${ }^{19,20}$ According to the structure of the drug target, the interaction between a small-molecule drug and the target protein can be studied by the molecular docking technique, and then the structure of the small molecule can be optimized. Hence, in this study, the interaction between cochinchinenin $\mathrm{C}$ and GLP-1 receptor was first determined through computer simulation. Then, this interaction was verified by fluorescence spectroscopy. The levels of insulin secretion, intracellular ATP, cAMP, and glucose in medium and mRNA gene insulin secretion were also determined after incubation of cochinchinenin $\mathrm{C}$ in a glucose-dependent manner. Finally, we proposed that cochinchinenin $\mathrm{C}$ is a potential nonpeptide GLP-1 receptor agonist.

\section{Material and methods}

\subsection{Materials}

The recombinant protein GLP1 receptor was purchased from Creative BioMart and used without further purification, configured as $25 \mathrm{mM}$. Cochinchinenin $\mathrm{C}$ was purchased from National Institutes for Food and Drug Control, and the stock solution of Cochinchinenin C (CC) was prepared in DMSO at $0.01 \mathrm{~mol} \mathrm{~L}^{-1}$. Here, $50 \mathrm{mM}$ Tris-HCl buffer was used to adjust the $\mathrm{pH}$ to 7.4. KRB buffer was composed of $129 \mathrm{mM} \mathrm{NaCl}$, $4.8 \mathrm{mM} \mathrm{KCl}, 1.2 \mathrm{mM} \mathrm{MgSO}{ }_{4}, 1.2 \mathrm{mM} \mathrm{KH}_{2} \mathrm{PO}_{4}, 2.5 \mathrm{mM} \mathrm{CaCl}_{2}$, $5 \mathrm{mM} \mathrm{NaHCO}_{3}, 10 \mathrm{mM}$ HEPES, and 0.1\% BSA, pH 7.4.

\subsection{Molecular docking}

The structure of GLP1 receptor (4ZGM) was obtained from the PDB database (http://www.rcsb.org/pdb). The molecular structure of cochinchinenin $\mathrm{C}$ was obtained from the PubChem database (https://pubchem.ncbi.nlm.nih.gov). Discovery Studio 4.1 software was used to simulate the interaction between cochinchinenin C and GLP1 receptor.

\subsection{Three-dimensional and two-dimensional fluorescence spectrometry}

Three-dimensional fluorescence spectra were obtained at a constant GLP1 receptor concentration $\left(0.025 \mu \mathrm{mol} \mathrm{L}^{-1}\right)$ in the absence or presence of cochinchinenin C $\left(0.05 \mu \mathrm{mol} \mathrm{L}^{-1}\right)$. Twodimensional fluorescence spectra were also obtained at a constant GLP-1 receptor concentration $\left(0.025 \mu \mathrm{mol} \mathrm{L}^{-1}\right)$ in the absence or presence of cochinchinenin C $\left(0-0.045 \mu \mathrm{mol} \mathrm{L}{ }^{-1}\right)$. Emission spectra were recorded from 290 to $500 \mathrm{~nm}$ when excitation was applied at $280 \mathrm{~nm} . F_{0}$ and $F$ represent the fluorescence intensity of GLP-1 receptor in the absence and presence of cochinchinenin $\mathrm{C}$ at an emission wavelength of $340 \mathrm{~nm}$, respectively. Other experimental parameters were as follows: slit width, $5 \mathrm{~nm}$; and voltage, $950 \mathrm{~V}$.

\subsection{The quenching mechanism}

Stern-Volmer quenching constant $\left(K_{\text {sv }}\right)$ and bimolecular quenching rate constant $\left(\boldsymbol{K}_{\mathbf{q}}\right)$. Fluorescence spectrometry was performed at different temperatures $(300,305$, and $310 \mathrm{~K})$ to obtain the fluorescence spectra. Here, the Stern-Volmer equation (eqn (1)) was used,

$$
F_{0} / F=1+K_{\mathrm{sv}}[\mathrm{C}]=1+K_{\mathrm{q}} \tau_{0}[\mathrm{C}]
$$

where the slope of the equation represents the Stern-Volmer quenching constant $\left(K_{\mathrm{sv}}\right)$. Eqn (2) was also used to calculate $K_{\mathrm{q}}$ :

$$
K_{\mathrm{sv}}=K_{\mathrm{q}} \tau_{0}
$$

( $\tau_{0}$ is the average lifetime of the protein without quencher, $\left.\tau_{0}=10^{-8} \mathrm{~s}\right)$.

Binding constant $\left(K_{\mathrm{a}}\right)$ and the number of binding sites $(n)$. Eqn (3) was used:

$$
\lg \left[\left(F_{0}-F\right) / F\right]=\lg K_{\mathrm{a}}+n \lg [\mathrm{C}],
$$

plotted to $\lg [\mathrm{C}]$ with $\lg \left[\left(F_{0}-F\right) / F\right]$, and a linear equation was obtained. The slope of the equation is the number of binding sites $(n)$ and the intercept of the equation is $\lg K_{\mathrm{a}}$, from which $K_{\mathrm{a}}$ can be obtained.

Thermodynamic parameters. Eqn (4) was used:

$$
\ln K_{\mathrm{a}}=-\Delta H / R T+\Delta S / R,
$$


( $T$, absolute temperature; $R$, gas constant $\left.=8.3145 \mathrm{~J} \mathrm{~mol}^{-1} \mathrm{~K}^{-1}\right)$. Plotted to $1 / T$ with $\ln K_{\mathrm{a}}$ and obtained the linear equation. The slope of the equation is $-\Delta H / R$, and the intercept of the equation is $\Delta S / R$. The enthalpy change $(\Delta H)$ and entropy change $(\Delta S)$ were calculated. $\Delta G$ can be calculated from the following equation: $\Delta G=\Delta H-T \Delta S$.

\subsection{Ins-1 cell culture}

Ins- 1 cells, a rat pancreatic $\beta$-cell line purchased from ATCC (US state), were cultured in DMEM high-glucose medium with $10 \%$ fetal bovine serum (FBS), $100 \mathrm{U} \mathrm{mL}^{-1}$ penicillin, $100 \mu \mathrm{g} \mathrm{mL}$ streptomycin, $10 \mathrm{mmol} \mathrm{L}^{-1}$ HEPES, $2 \mathrm{mmol} \mathrm{L}^{-1}$ L-glutamine, $1 \mathrm{mmol} \mathrm{L}{ }^{-1}$ sodium pyruvate, and $50 \mu \mathrm{mol} \mathrm{L}^{-1} \beta$-mercaptoethanol at $37{ }^{\circ} \mathrm{C}$ in a humidified atmosphere and $5 \% \mathrm{CO}_{2}$. The culture medium was replaced every 2 days and passaged every four days following trypsinization. The subculture cells were seeded at a density of $5.0 \times 10^{5}$ cells per $\mathrm{mL}$.

\subsection{Insulin secretion}

To measure insulin secretion, Ins-1 cells were first seeded onto 24-well plates and cultured for $48 \mathrm{~h}$ to approximately $80-90 \%$ confluence. The cells were then washed twice with KRB buffer and starved for $2 \mathrm{~h}$ in KRB buffer. Next, cells were incubated in fresh KRB buffer containing $10^{-8} \mathrm{~mol} \mathrm{~L}^{-1}$ cochinchinenin $\mathrm{C}$ at different glucose concentrations $(0,5,10,20$, and $30 \mathrm{mM})$. Cellular supernatant was sampled for insulin secretion. Insulin was measured using Iodine $\left[{ }^{125} \mathrm{I}\right]^{-}$Insulin Radioimmunoassay Kit (Shanghai Xinfan Biotechnology Co., Ltd.).

\subsection{Cell viability}

To determine cell viability, Ins-1 cells were seeded onto 96-well plates, where they were incubated in culture medium containing $10^{-8} \mathrm{~mol} \mathrm{~L}^{-1}$ cochinchinenin $\mathrm{C}$ for different incubation times $(1,2,4$, and $8 \mathrm{~h})$. Cell viability was measured using Cell Counting Kit-8 (CCK-8) (Sangon Biotech (Shanghai) Co., Ltd.).

\subsection{Intracellular cAMP and ATP levels}

To measure the intracellular levels of cAMP and ATP, Ins-1 cells were seeded onto 96-well plates, where they were washed twice with KRB buffer and starved for $2 \mathrm{~h}$ in KRB buffer. Then, the cells were incubated in fresh KRB buffer containing $10^{-8}$ mol L ${ }^{-1}$ cochinchinenin $\mathrm{C}$ at different glucose concentrations $(0,5$, and $20 \mathrm{mM})$ for $2 \mathrm{~h}$. Intracellular cAMP was measured using the cAMP-Glo ${ }^{\mathrm{TM}}$ Assay Kit and the ATP level was determined using the CellTiter-Glo® Luminescent Kit (Promega Corporation).

\subsection{Glucose absorption}

To assay glucose absorption, Ins-1 cells were seeded onto 24well plates, where they were incubated in fresh KRB buffer containing $10^{-8} \mathrm{~mol} \mathrm{~L}^{-1}$ cochinchinenin $\mathrm{C}$ at different glucose concentrations $(0,5$, and $20 \mathrm{mM})$ for 4 and $8 \mathrm{~h}$. Cellular supernatant was sampled to detect the change of glucose content in the medium. Cellular supernatant were measured using Glucose Assay Kit (Sigma-Aldrich).

\subsection{Gene mRNA expression}

The relative expression of genes associated with insulin secretion was determined by quantitative RT-PCR using the Bio-Rad CFX96 PCR System. All data are expressed as the ratio of the target gene to $\beta$-actin expression.

The primer sequences used for PCR were as follows: pdx-1, $5^{\prime}$ aaatccaccaaagctcacgc- $3^{\prime}$ (forward) and $5^{\prime}$-aagttgagcatcactgccagc$3^{\prime}$ (reverse); ins, $5^{\prime}$-gacccgcaagtgccacaa- $3^{\prime}$ (forward) and $5^{\prime}$-tccacaagccacgcttctg- $3^{\prime}$ (reverse); and $\beta$-actin, $5^{\prime}$-cccatctatgagggttacgc- $3^{\prime}$ (forward) and $5^{\prime}$-tttaatgtcacgcacgatttc- $3^{\prime}$ (reverse).

\subsection{Statistical analysis}

All statistical analyses were conducted using the software IBM SPSS Statistical 20. Data were analyzed using one-way ANOVA. The threshold for statistical significance was set at $P<0.05$. Results are presented as mean $\pm \mathrm{SD}$.

\section{Results and discussion}

\subsection{The interaction between cochinchinenin C and GLP1 receptor}

In our study, the interaction between cochinchinenin $\mathrm{C}$ and GLP-1 receptor was first determined based on molecular docking. As seen in Fig. 2A, cochinchinenin $\mathrm{C}$ could bind to the extracellular domain of the GLP1 receptor. The site of action of cochinchinenin C-GLP-1 receptor was further analyzed. Cochinchinenin $\mathrm{C}$ mainly bound to amino acid residues Ser31, Leu32, Thr35, Val36, Tyr88 and Trp39 of the GLP-1 receptor through hydrophobic interactions (Fig. 2B and C). Hydrogen bonds also formed between cochinchinenin C and GLP-1 receptor (Table 1). As one of the small-molecule GLP-1 agonists, Boc5 was discovered. It was reported that Boc5 has the ability to increase the intracellular level of cAMP. ${ }^{21}$ Hence, the interaction between Boc5 and GLP-1 receptor was measured to compare the result for cochinchinenin C-GLP-1 receptor (Fig. 2D-F). Surprisingly, it could be found that amino acid residues Trp39, Trp88 and Leu32 were also the key residues between Boc5 and GLP-1 receptor. What's more, hydrophobic interactions and hydrogen bonds were also formed between Boc5 and GLP-1 receptor (Table 2). Therefore, it could be seen that cochinchinenin $\mathrm{C}$ might be the potential agonist of GLP-1 receptor.

Based on the results of molecular docking analysis, further study of the interaction between cochinchinenin C and GLP-1 receptor was performed by three-dimensional fluorescence spectroscopy. As shown in Fig. 3A, there were two characteristic fluorescence peaks upon excitation at $230 \mathrm{~nm}$ and $280 \mathrm{~nm}$. The luminescence at the excitation at $230 \mathrm{~nm}$ resulted from the structure of the protein polypeptide chain, ${ }^{22}$ while that at the excitation at $280 \mathrm{~nm}$ resulted from spontaneous fluorescence amino acid residues, tyrosine, tryptophan, and phenylalanine. ${ }^{23}$ However, cochinchinenin $\mathrm{C}$ has very weak fluorescence in solution. Hence, the fluorescence of GLP-1 receptor can be used as a probe to determine the interaction between cochinchinenin C and GLP-1 receptor based on the change of fluorescence intensity. The fluorescence peak at $347 \mathrm{~nm}$ upon excitation at 

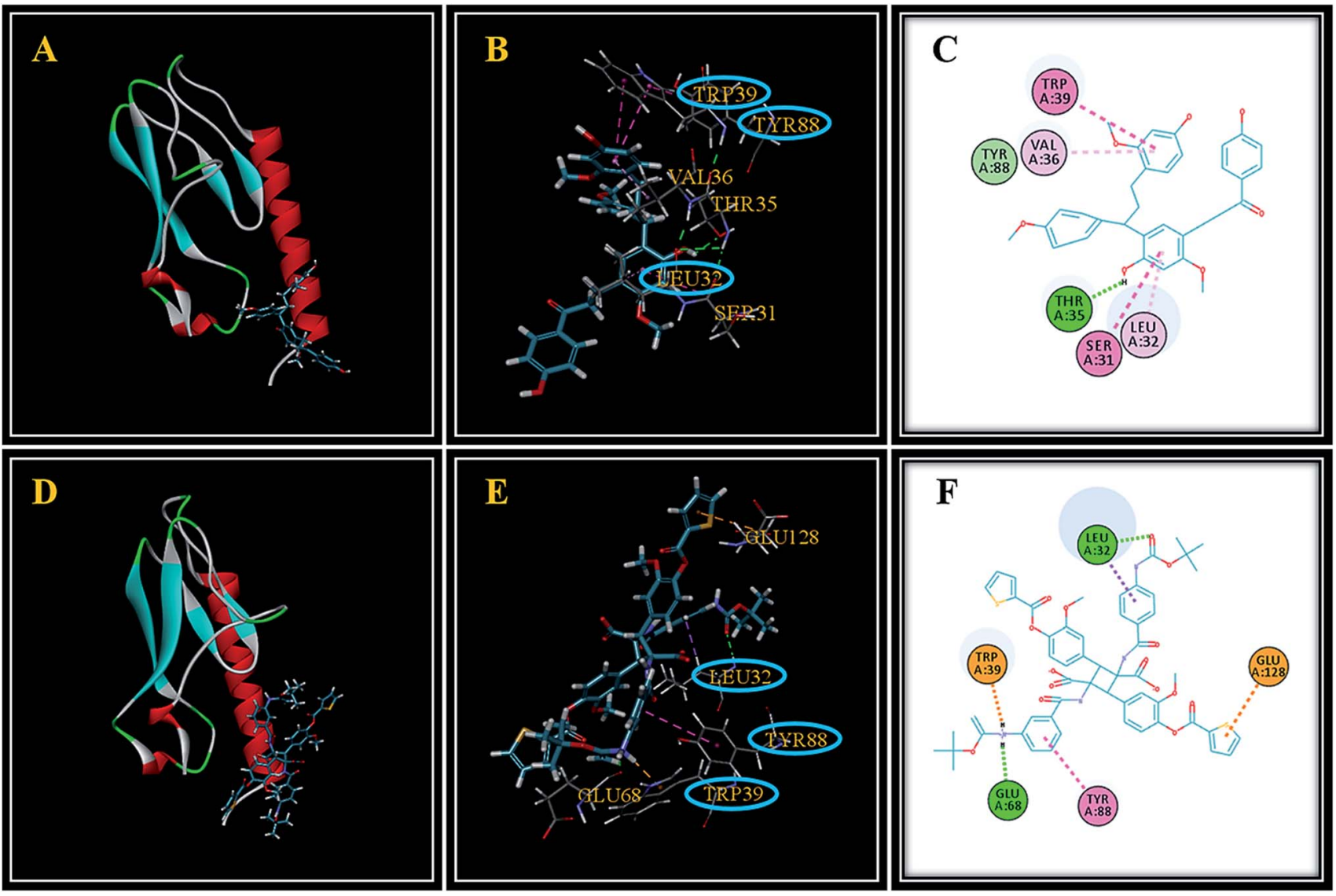

Fig. 2 Interaction between drugs and GLP-1 receptor through molecular docking. (A-C) Cochinchinenin C-GLP-1 receptor (D-F) Boc5-GLP-1 receptor.

Table 1 Parameters of the interaction between cochinchinenin C and GLP-1 receptor

\begin{tabular}{llll}
\hline Acting force & Bond length $(\AA)$ & From & To \\
\hline 4.74948 & Hydrophobic & GLP1R:TRP39 & CC \\
5.02218 & Hydrophobic & GLP1R:TRP39 & CC \\
4.94458 & Hydrophobic & GLP1R:SER31:C,O; LEU32:N & CC \\
4.34227 & Hydrophobic & CC & GLP1R:LEU32 \\
4.84843 & Hydrophobic & CC & GLP1R:VAL36 \\
2.19292 & Hydrogen bond & CC & GLP1R:THR35:OG1
\end{tabular}

Table 2 Parameters of the interaction between BOC5 and GLP-1 receptor

\begin{tabular}{llll}
\hline Acting force & Bond length $(\AA)$ & From & To \\
\hline 2.30382 & Hydrogen bond & GLP1R:LEU32:HN & BOC5 \\
1.96945 & Hydrogen bond & BOC5 & GLP1R:GLU68:O \\
2.38363 & Hydrogen bond & BOC5 & GLP1R:TRP39 \\
4.80812 & Electrostatic & GLP1R:GLU128:OE2 & BOC5 \\
2.85583 & Hydrophobic & GLP1R:LEU32:HB2 & BOC5 \\
5.68481 & Hydrophobic & GLP1R:TYR88 & BOC5 \\
& & & \\
\hline
\end{tabular}

$280 \mathrm{~nm}$ was selected. The fluorescence peak position remained unchanged after adding cochinchinenin $\mathrm{C}$, but the fluorescence intensity decreased by about 53.9\% (Fig. 3B). This showed that cochinchinenin $\mathrm{C}$ affected the fluorescence intensity of the GLP-1 receptor. Therefore, it was confirmed that cochinchinenin C did indeed interact with GLP-1 receptor. The interaction between cochinchinenin C and GLP-1 receptor was also studied by two-dimensional fluorescence spectroscopy. The fluorescence of GLP-1 receptor decreased upon the addition of cochinchinenin $\mathrm{C}$, which showed that there was an interaction between cochinchinenin C and GLP-1 receptor (Fig. 3C).

The overlap integral of the fluorescence emission spectra of GLP-1 receptor and the UV-vis spectra of cochinchinenin C (Fig. 3D) was calculated to obtain the critical energy transfer distance $R_{0}$. The following formula was used to determine the efficiency of nonradiative energy transfer $E$ between GLP-1 receptor and cochinchinenin C: $E=1-F / F_{0}=\left(R_{0}\right)^{6} /\left(\left(R_{0}\right)^{6}+\right.$ 
A

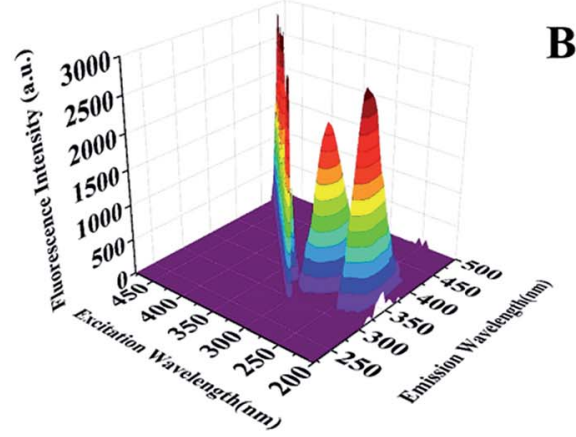

C

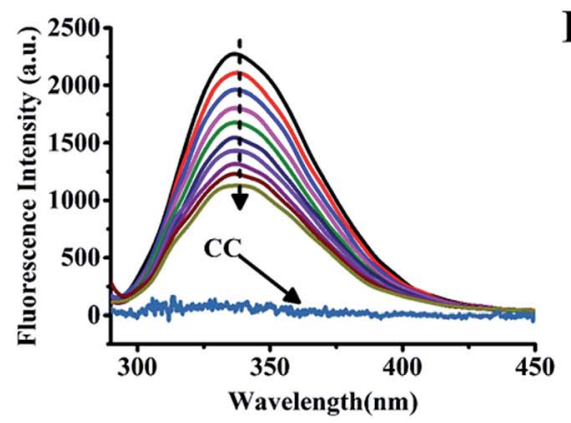

B

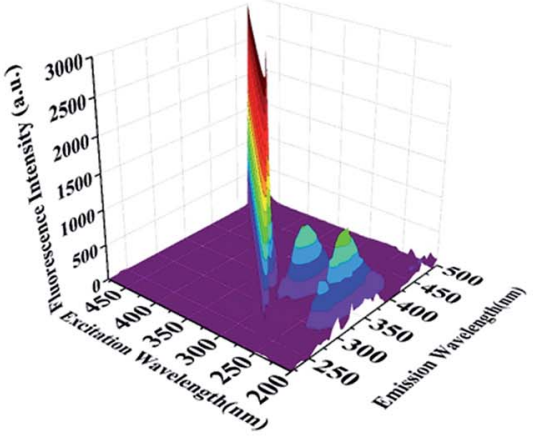

D

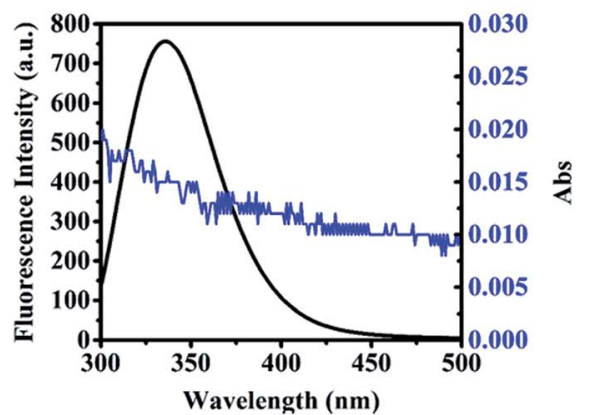

Fig. 3 Interaction between cochinchinenin C and GLP-1 receptor through spectral method. (A and B) GLP-1 receptor's three-dimensional fluorescence spectroscopy in the presence or absence of cochinchinenin C. (C) Two-dimensional fluorescence spectroscopy, keeping GLP-1 receptor' concentration constant $\left(0.025 \mathrm{~mol} \mathrm{~L}^{-1}\right)$ while varying the cochinchinenin $\mathrm{C}$ concentration from $0 \mathrm{~mol} \mathrm{~L}^{-1}$ to $0.045 \mathrm{~mol} \mathrm{~L}^{-1}$; fluorescence intensity of cochinchinenin $\mathrm{C}\left(0.025 \mathrm{~mol} \mathrm{~L}^{-1}\right)$ alone, line CC. (D) Overlap of the fluorescence spectra of GLP-1 receptor (0.025 mol $\left.\mathrm{L}^{-1}\right)$ and the absorption spectra of cochinchinenin $\mathrm{C}\left(0.05 \mathrm{~mol} \mathrm{~L}^{-1}\right)$.

$\left.(r)^{6}\right)$, where $F$ and $F_{0}$ are the fluorescence GLP-1 receptor intensity in the presence and absence of cochinchinenin $\mathrm{C}$. The distance $r$ between GLP-1 receptor and cochinchinenin C could be calculated according to Forster's theory. ${ }^{24}$ These parameters could be obtained: $E=0.39 \%, r=2.88 \mathrm{~nm}$. The donor-acceptor distance between cochinchinenin $\mathrm{C}$ and the tryptophan residue distance $R_{0}=2.79$, which was less than $7 \mathrm{~nm}$, and $0.5 R_{0}<r<$ $1.5 R_{0}$, indicating that nonradiative energy transfer occurred between cochinchinenin C and GLP-1 receptor.

\subsection{Quenching mechanism of the interaction between cochinchinenin C and GLP-1 receptor}

Two-dimensional fluorescence spectroscopy was performed at different temperatures $(300,305$, and $310 \mathrm{~K})$ while varying the concentration of cochinchinenin C from 0 to $0.045 \mu \mathrm{mol} \mathrm{L}^{-1}$ (Fig. 4). As shown in Table 3, the $K_{\mathrm{sv}}$ value of cochinchinenin CGLP-1 receptor gradually increased with increasing temperature. This suggested that the fluorescence quenching between cochinchinenin C and GLP-1 receptor might be dynamic because molecules moved faster in the solution with increasing temperature, which increased the probability of a collision between the excited-state fluorescence molecule and the quenching agent. In addition, the binding constant $K_{\mathrm{a}}$ and the number of binding sites $n$ between cochinchinenin C and GLP-1 receptor were calculated. The results revealed that the binding constant between cochinchinenin $\mathrm{C}$ and GLP-1 receptor increased with increasing temperature and the binding constant is approximately 1 .
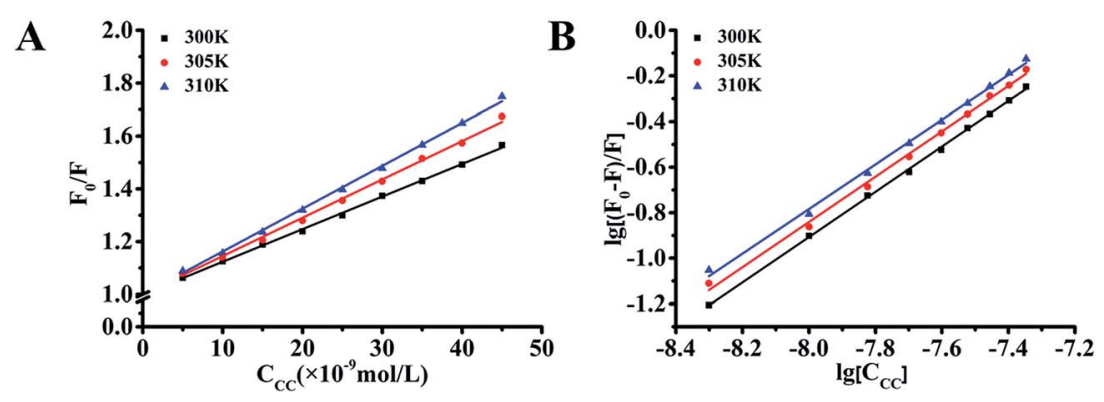

Fig. 4 Thermodynamic parameters of the interaction between cochinchinenin C and GLP-1 receptor. (A) Stern-Volmer curves of GLP-1 receptor fluorescence quenched cochinchinenin C. (B) Double-log plots of cochinchinenin C quenching effect on GLP-1 receptor's fluorescence. 
Table 3 Quenching constant $K_{\mathrm{sv}}$, quenching rate constant $K_{\mathrm{q}}$, binding constant $K_{\mathrm{a}}$, and binding site $n$ of cochinchinenin C with GLP1 receptor

\begin{tabular}{|c|c|c|c|c|c|}
\hline Compound & $T(\mathrm{~K})$ & $K_{\mathrm{sv}}\left(\times 10^{6} \mathrm{~L} \mathrm{~mol}^{-1}\right)$ & $K_{\mathrm{q}}\left(\times 10^{14} \mathrm{~L} \mathrm{~mol}^{-1}\right)$ & $K_{\mathrm{a}}\left(\times 10^{6} \mathrm{~L} \mathrm{~mol}^{-1}\right)$ & $n$ \\
\hline \multirow[b]{2}{*}{ Cochinchinenin $\mathrm{C}$} & 300 & 1.24 & 1.24 & 7.05 & 0.99 \\
\hline & 305 & 1.45 & 1.45 & 7.12 & 0.99 \\
\hline
\end{tabular}

Table 4 Thermodynamic parameters of cochinchinenin C-GLP1 receptor interaction

\begin{tabular}{lllll}
\hline Compound & $T(\mathrm{~K})$ & $\begin{array}{l}\Delta H \\
\left(\mathrm{~K} \mathrm{~J}^{-1} \mathrm{~mol}\right)\end{array}$ & $\begin{array}{l}\Delta G \\
\left(\mathrm{~K} \mathrm{~J}^{-1} \mathrm{~mol}\right)\end{array}$ & $\begin{array}{l}\Delta S \\
\left(\mathrm{~J} \mathrm{~mol}^{-1} \mathrm{~K}^{-1}\right)\end{array}$ \\
\hline \multirow{3}{*}{ Cochinchinenin C } & 300 & & -40.52 & \\
& 305 & 18.90 & -41.51 & 198.05 \\
& 310 & & -42.50 & \\
\hline
\end{tabular}

The thermodynamic parameters of the interaction between cochinchinenin C and GLP-1 receptor could be calculated using the following equation: $\ln K_{\mathrm{a}}=-\Delta H / R T+\Delta S / R . \Delta G$ could also be calculated using the following equation: $\Delta G=\Delta H-T \Delta S$. As shown in Table 4, enthalpy change $(\Delta H)$ and entropy change in the process of binding between cochinchinenin C and GLP-1 receptor were obtained, namely, $\Delta H>0, \Delta S>0$. Based on the thermodynamics regular of the acting force between drug and biomacromolecule, ${ }^{25}$ it was indicated that hydrophobic force was the main factor in the binding between cochinchinenin $\mathrm{C}$ and GLP-1 receptor, which is consistent with the results from molecular simulation. Then, the Gibbs free energy of cochinchinenin C-GLP-1 receptor was calculated to be less than 0 , which proved that the interaction was spontaneous.

\subsection{Effect of cochinchinenin C on the conformation of GLP-1 receptor}

Synchronous fluorescence is usually used to determine the effects of drugs on the conformation of a target protein. ${ }^{26}$ The synchronous fluorescence spectra of a protein upon addition of a compound at $\Delta \lambda=15$ and $60 \mathrm{~nm}$ show the spectral characteristics of tyrosine and tryptophan residues, respectively. In this experiment, the synchronous fluorescence spectra of GLP-1 receptor upon addition of cochinchinenin $\mathrm{C}$ at $\Delta \lambda=15$ and
$60 \mathrm{~nm}$ were obtained at a constant GLP-1 receptor concentration $\left(0.025 \mathrm{~mol} \mathrm{~L}^{-1}\right)$, while varying the concentration of cochinchinenin $\mathrm{C}$ from 0 to $0.045 \mu \mathrm{mol} \mathrm{L}^{-1}$, as shown in Fig. 5A and $B$. In synchronous fluorescence spectra of GLP-1 receptor upon the addition of cochinchinenin $\mathrm{C}$ at $\Delta \lambda=15$, the maximum excitation wavelength showed a blue shift accompanied by fluorescence quenching. When $\Delta \lambda=60 \mathrm{~nm}$, the maximum excitation wavelength hardly changed and the fluorescence intensity was still quenched. In summary, the degree of fluorescence quenching at $\Delta \lambda=60 \mathrm{~nm}$ was higher than that at $\Delta \lambda=15 \mathrm{~nm}$, and it was also inferred that the fluorescence quenching of tryptophan residues was much greater than that of tyrosine residues. It was revealed that the fluorescence quenching between cochinchinenin C and GLP-1 receptor was mainly caused by the effect of cochinchinenin $\mathrm{C}$ on tryptophan residues. When $\Delta \lambda=15 \mathrm{~nm}$, the maximum excitation wavelength showed a red shift because the microenvironment of tyrosine residues in the GLP-1 receptor was affected by the addition of cochinchinenin $\mathrm{C}$. Therefore, the results showed that cochinchinenin $\mathrm{C}$ affected the conformation of the GLP-1 receptor.

\subsection{Effect of cochinchinenin $\mathrm{C}$ on insulin secretion and cell activity of Ins-1 cells}

In this experiment, the effect of cochinchinenin $\mathrm{C}$ on insulin secretion was first measured at different glucose concentrations. Glucose-stimulated insulin secretion (GSIS) is an important element on the function of $\beta$-cell and for the cure of type 2 diabetes mellitus. As shown in Fig. 6A, cochinchinenin $\mathrm{C}$ significantly promoted insulin secretion in medium with 10 and $20 \mathrm{mM}$ glucose. When the glucose concentration was $10 \mathrm{mM}$ in medium, the promotion of insulin secretion in the cochinchinenin C-treatment group reached the highest value $(3.79 \pm 0.18$ IU $\mathrm{mL}^{-1}$ ), which was about 1.35 -fold higher than that in the
A

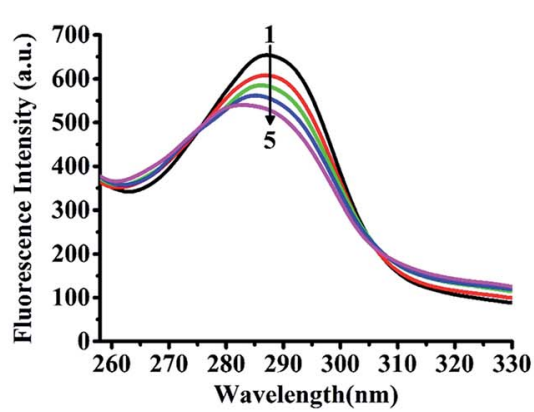

B

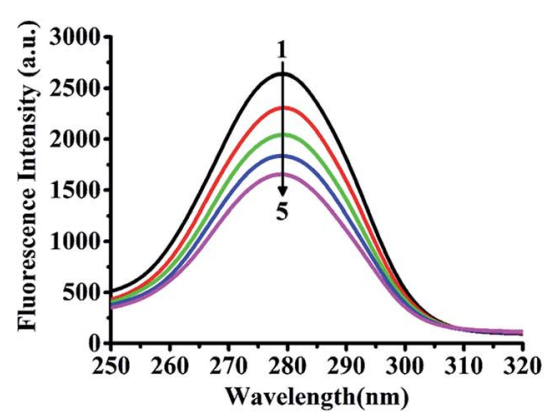

Fig. 5 Synchronous fluorescence of the interaction between cochinchinenin C and GLP-1 receptor. (A) $\Delta \lambda=15 \mathrm{~nm}$; (B) $\Delta \lambda=60 \mathrm{~nm}$. 
A

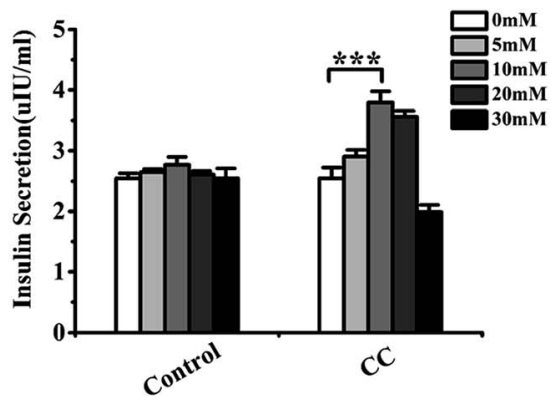

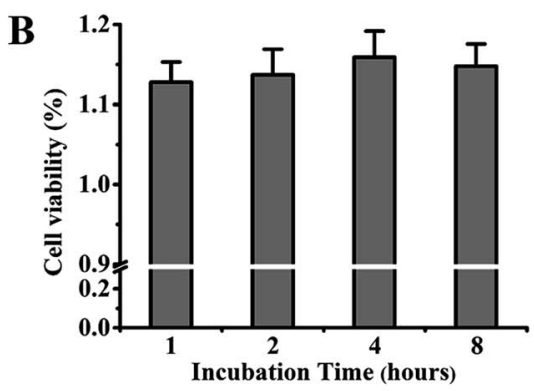

Fig. 6 Effect of cochinchinenin $C$ on insulin secretion and cell viability of Ins-1 cells. (A) Effect of cochinchinenin $C$ on insulin secretion at the condition of different glucose concentration. (B) The cell viability of Ins-1 cells with the incubation of cochinchinenin C compared with the control group. ( $n=5, * * * p<0.005)$.

control group. In contrast, when the glucose concentration was $30 \mathrm{mM}$ in medium, insulin secretion was inhibited in the cochinchinenin C-treatment group. It could be speculated that the function of pancreatic beta cell was affected in such a high glucose concentration. Liu et al. found that geniposide, a potential anti-diabetic drug targeting for GLP-1 receptor, also inhibited insulin secretion at the condition of $33 \mathrm{mM}$ glucose. ${ }^{27}$ Therefore, it could be obtained that cochinchinenin $\mathrm{C}$ enhanced the promotion of insulin secretion in the presence of low or moderately high glucose concentration.

Cell activity tests are usually applied to estimate cytotoxicity upon treatment with drugs. Cell Counting Kit-8 (CCK-8) enables the sensitive determination of cell viability via cell proliferation and cytotoxicity assays based on the change of mitochondrial dehydrogenase to formazan. Specifically, cell proliferation and cytotoxicity could be determined through the detection of OD at $450 \mathrm{~nm}$. In this experiment, cell viability was measured upon incubation for $1,2,4$, and $8 \mathrm{~h}$ after adding $10^{-8} \mathrm{M}$ cochinchinenin $\mathrm{C}$ to the culture medium (Fig. 6B). The results showed that the survival rate of Ins-1 cells increased with increasing incubation time. Therefore, it was revealed that cochinchinenin $\mathrm{C}$ exhibited almost no toxicity to cells and could be used in further experiments.

\subsection{Mechanism of the effect of cochinchinenin $\mathrm{C}$ on insulin secretion in Ins-1 cells}

Intracellular cAMP levels are commonly measured to determine whether extracellular signaling molecules are associated with cell surface receptors. ${ }^{28,29}$ Patients are judged to be suffering from diabetes mellitus if their blood glucose concentration is greater than or equal to $7 \mathrm{mmol} \mathrm{L}^{-1}$. Hence, 5 and $20 \mathrm{mM}$ glucose levels were used in this experiment. The intracellular cAMP content was determined after incubation of cochinchinenin $\mathrm{C}$ for $2 \mathrm{~h}$, so as to estimate whether cochinchinenin $\mathrm{C}$ activated the GLP-1 receptor on the cell surface. As shown in Fig. 7A, the content of cAMP increased with increasing glucose
A

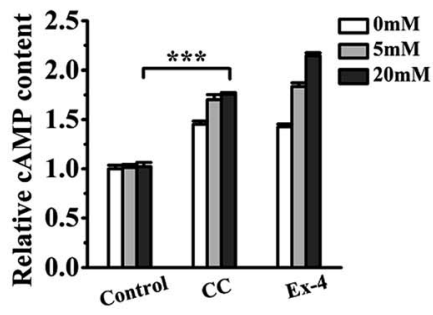

B

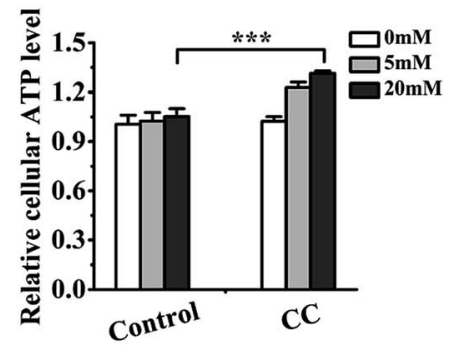

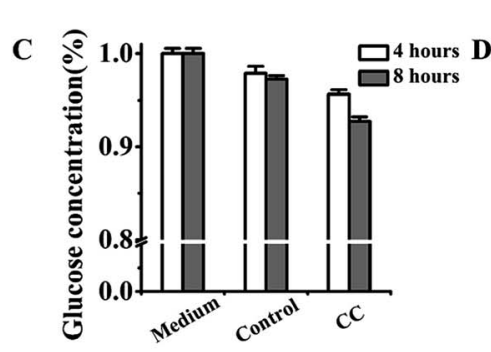
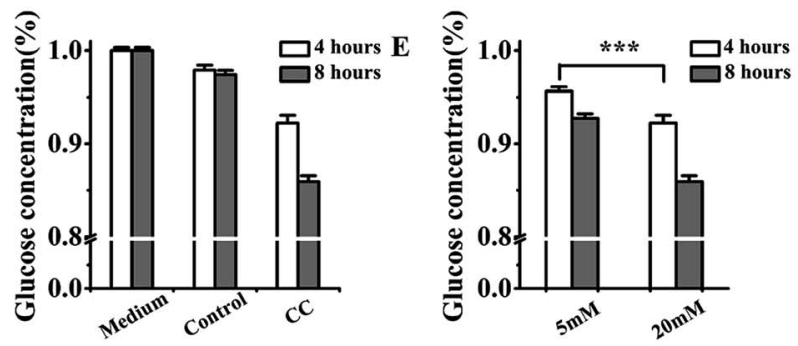

Fig. 7 Effect of cochinchinenin C on intracellular CAMP content, ATP level, and glucose absorption. (A) The change of intracellular cAMP content with the treatment of cochinchinenin C. (B) The change of intracellular ATP level with the treatment of cochinchinenin C. (C-E) The decrease of glucose concentration in medium was detected with the effect of cochinchinenin C. (C) $5 \mathrm{mM}$ glucose-treated group; (D) $20 \mathrm{mM}$ glucosetreated group; (E) comparison of capacity about glucose absorption in $5 \mathrm{mM}$ glucose-treated group with $20 \mathrm{mM}$ glucose-treated group. $(n=5$, $* * * P<0.005)$. 
concentration upon cochinchinenin $\mathrm{C}$ treatment, but lower than the Ex-4 group which is a GLP-1 receptor agonist. Therefore, it could be determined that the level of cAMP increased owing to the combination with GLP-1 receptor, then activated adenylate cyclase and finally caused the increase of intracellular cAMP.

In pancreatic beta cells, the level of intracellular ATP plays a critical role in insulin secretion. ${ }^{30}$ The increase in ATP/ADP ratio leads to the closure of ATP-sensitive $\mathrm{K}$ channels $\left(K_{\mathrm{ATP}}\right)$, causes the influx of calcium ions, and ultimately produces insulin secretion. Fig. 7B shows that the intracellular ATP level increased with increasing glucose concentration in the culture medium upon treatment with cochinchinenin C. Comparing the condition of $5 \mathrm{mM}$ glucose with $20 \mathrm{mM}$ glucose, the intracellular ATP level clearly increased with $20 \mathrm{mM}$ glucose. The promotion of insulin secretion was related to the increase of intracellular ATP level. Furthermore, glucose content in cellular supernatant was measured before and after the treatment with cochinchinenin C.

As shown in Fig. 7C-E, upon treatment with cochinchinenin $\mathrm{C}$ for 4 and $8 \mathrm{~h}$, glucose in cellular supernatant decreased at the conditions of 5 and $20 \mathrm{mM}$, respectively, which suggested that cochinchinenin $\mathrm{C}$ has the ability to promote glucose absorption. The glucose absorption by Ins-1 cells upon treatment with cochinchinenin $\mathrm{C}$ was also compared between the 5 and $20 \mathrm{mM}$ conditions. Cochinchinenin C clearly promoted glucose absorption in the $20 \mathrm{mM}$ condition upon incubation for $4 \mathrm{~h}$. Hence, it could be concluded that elevated intracellular ATP levels were dependent on the constant metabolism of glucose in the medium upon treatment with cochinchinenin C. Because of the activation of GLP-1 receptor, some of the ATP generated by glucose metabolism changed into cAMP.

\subsection{Effect of cochinchinenin $\mathrm{C}$ on the gene expression related to insulin secretion}

In this experiment, the gene mRNA expression of Ins- 1 cells was determined upon incubation with cochinchinenin C. Pdx-1, a transcription factor encoded by the pdx-1 gene, plays an important role in the development and differentiation of pancreatic cells. ${ }^{31,32}$ It can promote the proliferation of pancreatic beta cells. GLP-1 has been reported to promote Pdx-1 expression in a glucose-dependent manner. Upon treatment with cochinchinenin $\mathrm{C}$, gene mRNA expression related to insulin secretion was measured. As shown in Fig. 8, the gene
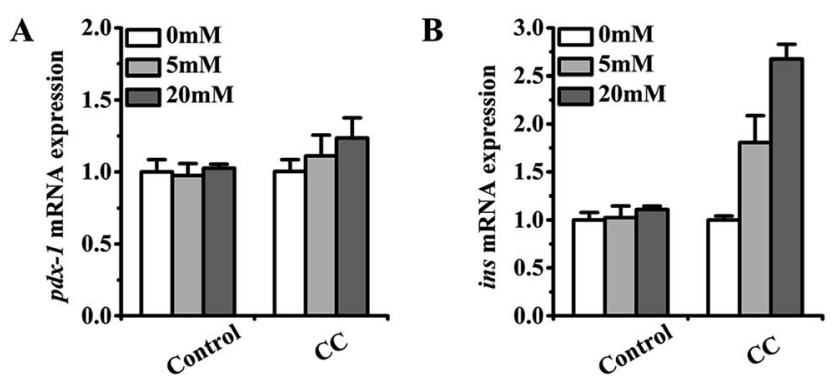

Fig. 8 Effect of cochinchinenin $C$ on gene mRNA expression.
mRNA expression of pdx-1 and ins increased upon treatment with cochinchinenin $\mathrm{C}$. In addition, the expression of pdx-1 and ins was clearly enhanced by the treatment with cochinchinenin $\mathrm{C}$ compared with that in the control group under the condition of a glucose concentration of $20 \mathrm{mM}$. Therefore, it could be speculated that cochinchinenin $\mathrm{C}$ affected the expression of genes related to insulin secretion, thereby promoting such secretion.

As a class of B G protein-coupled receptor, GLP-1 receptor has an ability to mediate the action of GLP-1, which is useful in diabetes treatment. Cochinchinenin $\mathrm{C}$, extracted from sangusis draconis, might be the potential GLP-1 receptor agonist through molecular docking, spectral experiment and cell experiment. Currently, the development of computer-aided drug design provides us with more convenience to estimate the interaction between drugs with target protein. Hence, the exploration of new drug discovery has become more rapidly than before. Fluorescence spectroscopy, a general method, was commonly applied to estimate the interaction between drug and biomolecule based on the changing of fluorescence. The results from spectrum could verify the interaction between cochinchinenin C and GLP-1 receptor obtained from computational simulation. Besides spectrum and molecular docking, the efficacy and mechanism of cochinchinenin $\mathrm{C}$ were also determined. Generally, the treatment of diabetes was dependent on how to control blood sugar. Glucose-stimulated insulin secretion is an important element on the function of $\beta$-cell. It is exciting to find that cochinchinenin $\mathrm{C}$ have the ability to promote insulin secretion with the increasing of blood sugar and also stop the efficacy at the normal blood sugar. What's more, the increasing of cAMP infers the activation of GLP-1 receptor with the incubation of cochinchinenin $\mathrm{C}$. There were also obtained the results of the increase of ATP level, the absorption of glucose and the enhancement of gene about insulin secretion with the effect of cochinchinenin C. Since cochinchinenin $\mathrm{C}$ has the well therapeutic effect, new diabetes drug based on the structure of cochinchinenin $\mathrm{C}$ will be developed. The optimization of molecular structure, improvement in water solubility, enhancement of efficacy and reduction of side effects will be the focus for us to expand further researches in the future.

\section{Conclusions}

In this study, it could be obtained that cochinchinenin $\mathrm{C}$ interacted well with GLP-1 receptor agonist based on fluorescence spectrometry and molecular docking. In addition, cell experiments showed that cochinchinenin C activated the GLP-1 receptor and then enhanced intracellular cAMP level. Hence, we proposed that cochinchinenin $\mathrm{C}$ might be a potential nonpeptide GLP-1 receptor agonist.

Most of anti-diabetic drugs targeting for GLP-1 receptor were peptide agonists, such as exendin-4, eventide, and liraglutide. Although they have better therapeutic effect, the disadvantages of peptide agonists were that they could be easily degraded by DPP4 and needed to be injected intravenously or subcutaneously which might cause pain for patients. Therefore, the exploration of nonpeptide GLP-1 receptor agonist become 
popular in research field for anti-diabetic drug. The aim of our study is to determine whether there is an interaction between cochinchinenin C and GLP-1 receptor in vitro. Actually, further experimental works including the interaction between cochinchinenin C and GLP-1 receptor in vivo should be designed. At the moment, the high-throughput screening model for GLP-1 receptor agonist is being established. With deep exploration, it is a hope that nonpeptide GLP-1 receptor agonist will be a more superior anti-diabetic drug choice and bring patients better therapeutic effect.

\section{Conflicts of interest}

There are no conflicts to declare.

\section{Acknowledgements}

The authors wish to thank Prof. Yonghua Ji from Shanghai University, School of life Sciences for supporting the molecular modeling software (Discovery Studio 4.1). This study was supported by a grant from the National Key Technology Support Program of China (No. 2013BAD12B06) and The National Key research and Development Program of China (No. 2016YFD0501101), and the experimental apparatus were provided by Experimental Center for Life Sciences of Shanghai University.

\section{References}

1 A. D. Assoc, Diabetes care, 2011, 34, S62-S69.

2 Z. Fu, E. R. Gilbert and D. Liu, Curr. Diabetes Rev., 2013, 9, 25-53.

3 E. Renstrom, S. Barg, F. Thevenod and P. Rorsman, Diabetes, 2002, 51, S33-S36.

4 M. B. Shaghafi, D. G. Barrett, F. S. Willard and L. E. Overman, Bioorg. Med. Chem. Lett., 2014, 24, 1031-1036.

5 J. E. Schopman, A. C. R. Simon, S. J. M. Hoefnagel, J. B. L. Hoekstra, R. J. P. M. Scholten and F. Holleman, Diabetes/Metab. Res. Rev., 2014, 30, 11-22.

6 D. Tornehave, P. Kristensen, J. Romer, L. B. Knudsen and R. S. Heller, J. Histochem. Cytochem., 2008, 56, 841-851.

7 E. C. Tibaduiza, C. Chen and M. Beinborn, J. Biol. Chem., 2001, 276, 37787-37793.

8 J. M. Egan, C. Montrose-Rafizadeh, Y. Wang, M. Bernier and J. Roth, Endocrinology, 1994, 135, 2070-2075.

9 A. A. Tahrani, A. H. Barnett and C. J. Bailey, Nat. Rev. Endocrinol., 2016, 12, 566-592.

10 A. Uccellatore, S. Genovese, I. Dicembrini, E. Mannucci and A. Ceriello, Diabetes Ther., 2015, 6, 239-256.
11 A. R. Meloni, M. B. DeYoung, C. Lowe and D. G. Parkes, Diabetes, Obes. Metab., 2013, 15, 15-27.

12 C. Alarcon, B. Wicksteed and C. J. Rhodes, Diabetologia, 2006, 49, 2920-2929.

13 J. Nagakura, T. Yamakawa, M. Taguri, H. Tsuchiya, E. Shigematsu, J. Suzuki, S. Morita, K. Kadonosono and Y. Terauchi, Endocr. J., 2016, 63, 239-247.

14 C. F. Deacon, M. A. Nauck, M. Toft-Nielsen, L. Pridal, B. Willms and J. J. Holst, Diabetes, 1995, 44, 1126-1131.

15 D. Gupta, B. Bleakley and R. K. Gupta, J. Ethnopharmacol., 2008, 115, 361-380.

16 C. M. Hu, J. S. Li, K. P. Cheah, C. W. Lin, W. Y. Yu, M. L. Chang, G. C. Yeh, S. H. Chen, H. W. Cheng and C. S. Choy, Diabetes Res. Clin. Pract., 2011, 94, 417-425.

17 J. Y. Fan, T. Yi, C. M. Sze-To, L. Zhu, W. L. Peng, Y. Z. Zhang, Z. Z. Zhao and H. B. Chen, Molecules, 2014, 19, 10650-10669.

18 R. Zhang, Tradit. Chin. Drug Res. Clin. Pharmacol., 2002, 13, 3.

19 A. Tropsha and J. Bajorath, J. Med. Chem., 2016, 59, 1.

20 C. H. Reynolds, Curr. Pharm. Des., 2014, 20, 3380-3386.

21 F. Lin and R. X. Wang, J. Mol. Model., 2009, 15, 53-65.

22 B. Niu, M. Zhang, P. Du, L. Jiang, R. Qin, Q. Su, F. Chen, D. Du, Y. Shu and K. C. Chou, OncoTargets Ther., 2017, 8, 57149-57162.

23 X. Chen, K. Qian and Q. Chen, Eur. J. Med. Chem., 2015, 93, 492-500.

24 T. Forster and O. Sinanoglu, Modern Quantum Chemistry, 1996, pp. 93-138.

25 P. D. Ross and S. Subramanian, Biochemistry, 1981, 20, 30963102.

26 L. Zhang, B. Liu, Z. Li and Y. Guo, Luminescence, 2015, 30, 686-692.

27 J. H. Liu, L. X. Guo, F. Yin, Y. L. Zhang, Z. X. Liu and Y. W. Wang, PLoS One, 2013, 8(10), e78315.

28 F. Schwede, O. G. Chepurny, M. Kaufholz, D. Bertinetti, C. A. Leech, O. Cabrera, Y. M. Zhu, F. Mei, X. D. Cheng, J. E. M. Fox, P. E. MacDonald, H. G. Genieser, F. W. Herberg and G. G. Holz, Mol. Endocrinol., 2015, 29, 988-1005.

29 E. P. Smith, Z. B. An, C. Wagner, A. G. Lewis, E. B. Cohen, B. L. Li, P. Mahbod, D. Sandoval, D. Perez-Tilve, N. Tamarina, L. H. Philipson, D. A. Stoffers, R. J. Seeley and D. A. D'Alessio, Cell Metab., 2014, 19, 1050-1057.

30 G. W. Cline, R. L. Pongratz, X. J. Zhao and K. K. Papas, Biochem. Biophys. Res. Commun., 2011, 415, 30-35.

31 C. M. McKinnon and K. Docherty, Diabetologia, 2001, 44, 1203-1214.

32 X. L. Wang, C. M. Cahill, M. A. Pineyro, J. Zhou, M. E. Doyle and J. M. Egan, Endocrinology, 1999, 140, 4904-4907. 